\title{
Modelling Groundwater Potential using Geospatial Technologies in Meru County, Kenya
}

\author{
Gitonga, D and Eshton, B. \\ DOI: 10.29322/IJSRP.10.07.2020.p10363 \\ http://dx.doi.org/10.29322/IJSRP.10.07.2020.p10363
}

\begin{abstract}
Spatial analysis is key to mitigating ground water resource problem related to lack of reconnaissance prior to prospecting using terrameter. Traditionally, time consuming and expensive resistivity measurements are indiscriminately applied for feasibility of ground water potential. The results have often led to exploitation of dry ground wells. Ground water modelling is essential to preliminarily identify potential sites for deployment of resistivity mesurements. Major economic activity in Meru County is rain-fed agriculture solely dependent on erratic rainfall. The big disparity in altitude and rainfall impacts on availability of reliable water sources especially during the dry season when locals travel long distances in search of water. The groundwater potential mapping will support exploitation in an effort to compliment available water sources in the county. The purpose of this study was to model ground water suitability site in Meru County using Geographic Information Systems/Remote Sensing (GIS/RS) technologies. The study adopted quantitative research designs. This was achieved through application of GIS/RS technologies that entailed preparation, evaluation, modeling and interpretation of parameters touching on climate, geophysics and geology data. The dataset were appropriately weighted in a modified DRASTIC based overlay scheme. Software's used for the study included: GIS ArcGIS (V 10.1) with Spatial Analyst, 3D Analyst, ArcHydro and SWAT extensions. RS ERDAS Imagine 9.3 and ENVI 4.7.The study revealed the most suitable areas for groundwater prospecting are in the central, northern and eastern areas of the county. Existing water points are available in these regions and thus served to validate the study findings. The study recommends in these regions studies to verify the variations in DRASTIC factors and the prevailing water quality.
\end{abstract}

Index Terms- Geographic Information Systems, Remote Sensing, DRASTIC model, Meru County.

\section{INTRODUCTION}

$\mathrm{G}$ IS/RS analysis has been widely used, often with great success in environmental assessment and monitoring. However, there is limited use in prospecting of ground water resources (Rahman, 2008). The original DRASTIC model was developed to map groundwater pollution potential developed by Aller et al. (1987). It features seven factors (depth to water, recharge, Aquifer media, soil media, topography (slope), impact of the Vadose zone and Conductivity of the aquifer), that are weighted according to the significance of each factor in determining pollution potential. The resulting weighted overlay then depicts the pollution potential for each spatial region

\section{GROUND WATER OCCURRENCE}

Groundwater is one of the earth's most important resources and its development can play a big role in a country's economy. It becomes a usable resource when the water bearing formations are permeable enough to allow water to infiltrate through them, to yield adequate quantity of good quality water for use through boreholes, dug-wells and springs, and can be replenished from recharge sources to permit continued exploitation forming a vital resource for agriculture, domestic and industry water supply. It is also the single largest and most productive source of irrigation water and plays a critical role in maintaining agricultural production during droughts. Groundwater can therefore be exploited if potential areas with abundant groundwater can be identified (Murphy, 2000).

\section{APPLICATION OF DRASTIC MODEL IN GROUND WATER MAPPING}

A variety of techniques are used to give information on potential occurrence of groundwater since it cannot be seen directly from the earth's surface as argued by Ganapuram et al. (2009). Systematic planning of groundwater development using modern techniques is essential for proper utilization and management of this natural resource (Kamaraju, 1996). As posited by Kumar (2010), the existing methods for groundwater exploration using geophysical and geo-electrical techniques are expensive and time consuming hence there is a need to exploit new technologies of GIS/RS in the exploration of groundwater. Remote sensing (RS), with its advantages of spatial, spectral and temporal availability of data covering large and inaccessible areas within short time has become a very rapid and cost effective tool in assessing, monitoring and conserving groundwater resources. According to Kuria et al. (2012) Geographical Information System (GIS) on the other hand, is a powerful environment for real time database development, especially in studies such as delineating groundwater potential zones and recharge sites.

In mapping ground water, the factors that are used are Lithology, Surface drainage density, Soil types, Slope steepness, Rainfall distribution, land-cover and topography, with the spatial overlay concepts used in the DRASTIC methodology as described by Pandiyani and Annadurai (2013).

Drainage/lineaments, lithology and topography define geology and geomorphology data employed with their significant influence exhibited through the various landforms and structural features (Crawford \& Brackett, 1995). Lineaments are commonly surface expressions of tectonic fractures and faults in the bedrock, 
emphasized on the surface by topography, drainage, and vegetation and can be identified by remotely sensed data. Drainage density is defined as the closeness of spacing of stream channels. It is a measure of the total length of the stream segment of all orders per unit area. Drainage provides recharge to groundwater hence higher potential where there is high drainage density. These features are favorable for the occurrence of groundwater and are classified in terms of groundwater potentiality. Some of these features are deciphered from remote sensing data. (Rao et al; 2009)

When groundwater moves through soil, the structure of the soil affects its movement. The three particles that determine soil structure are sand, silt and clay. The amount of groundwater recharge, storage, discharge, as well as the extent of groundwater presence all depend on the soil properties: texture (grain size, texture classification, soil series classification), porosity, specific yield and permeability attenuation capacity (Sankara, 2002).

Slope is the one of the factors controlling the infiltration of ground water into sub-surface; hence an indicator for the suitability for ground water prospect. In the gentle slope area the surface runoff is slow allowing more time for rain water to percolate, whereas high slope area facilitate high runoff allowing less residence time for rain water hence comparatively less infiltration as argued by Sener et al. (2005).

Rainfall and land cover determine the amount of water input and surface influence to infiltration respectively. Vegetation reduces amount of runoff thereby allowing longer time and higher infiltration of rainfall water that provides the major source of ground water. In view of the aforesaid factors, the DRASTIC Index provides only a relative evaluation tool and is not designed to provide absolute answers. Therefore, DRASTIC is a reconnaissance tool, but has proven its value as an indicator of areas deserving a detailed hydrogeological evaluation (Mati, 2005).

\section{GAP ANALYSIS}

A range of challenges exist that inhibit efficient, cost effective and sustainable exploration, development and use of ground water resources. The challenges include use of time and costly techniques of exploration and limited capacity within the sector domain to undertake ground water modelling. In Meru, the government is implementing a borehole program that is heavily relying on on-site geophysical investigation at the first instance without reconnaissance survey. Adoption of GIS/RS would improve on the siting of appropriate sites and save both time and cost, yet there exist limited empirical studies to address this concern. This study is an empirical attempt to fill this gap. Further, application of GIS/RS in ground water exploration and in particular the DRASTIC model is a recent phenomenon and has scantly been studied. This study addressed this knowledge gap by modelling the ground water potential based on modified DRASTIC model

\section{MATERIALS AND METHODS}

GIS/RS were employed in this research. Software's used for the study included: GIS ArcGIS (V 10.1) with Spatial Analyst, 3D Analyst, ArcHydro and SWAT extensions. RS ERDAS Imagine 9.3 and ENVI 4.7.

Table 1 shows the various data used with corresponding derivative employed in the model. Landsat imageries $(30 \mathrm{~m}$ resolution) were downloaded from the United States Geological Survey (USGS) website, topographic base map from the survey of Kenya, Advanced Spaceborne Thermal Emission and Reflection Radiometer, (ASTER). Digital Elevation Model (DEM) from NASA, with other data obtained from the International Livestock Research Institute (ILRI). Fig. 1 and 2 maps out the derivatives.

Table 1: Data and derivative employed in the model

\begin{tabular}{|c|c|c|}
\hline Data & Derived modeling variable & Data source \\
\hline $\begin{array}{l}\text { DEM and Landsat } 7 \text { ETM+ }(4 \\
\text { scenes) }\end{array}$ & $\begin{array}{l}\text { Surface drainage and lineament } \\
\text { density }\end{array}$ & USGS, ASTER \\
\hline Lithology & Lithology & ILRI \\
\hline Soil & Soil texture & ILRI \\
\hline DEM & Slope & ASTER \\
\hline Rainfall Data & Rainfall distribution & ILRI \\
\hline Land Use/Land Cover & Land cover & ILRI \\
\hline DEM and Topographic base map & Topography & $\begin{array}{l}\text { ASTER, Survey of } \\
\text { Kenya }\end{array}$ \\
\hline
\end{tabular}

Lineament mapping was undertaken based on geomorphological features such as aligned ridges and valleys, displacement of ridge lines, scarp faces and river passages, straight drainage channel segments, pronounced break in crystalline rock masses and aligned surface depression. Various data sets, including multispectral satellite imagery (Landsat) and DEM, as well as geological data describing fractures, faults, and hydrology were used to map and validate the lineament and drainage distribution in the study area. Lineaments were delineated by visual interpretation of the false color composite (FCC) 471. After all the lineaments were interpreted, they were merged with the DEM derived streams to form one dataset called Surface drainage and lineament shown as Figure 1. The DEM was also used to generate other features like hill shade shown as Figure 2, slope and topography. The results are presented as lineament and drainage density map. The zones of high lineament intersection density are feasible zones for groundwater prospecting in the study area. 


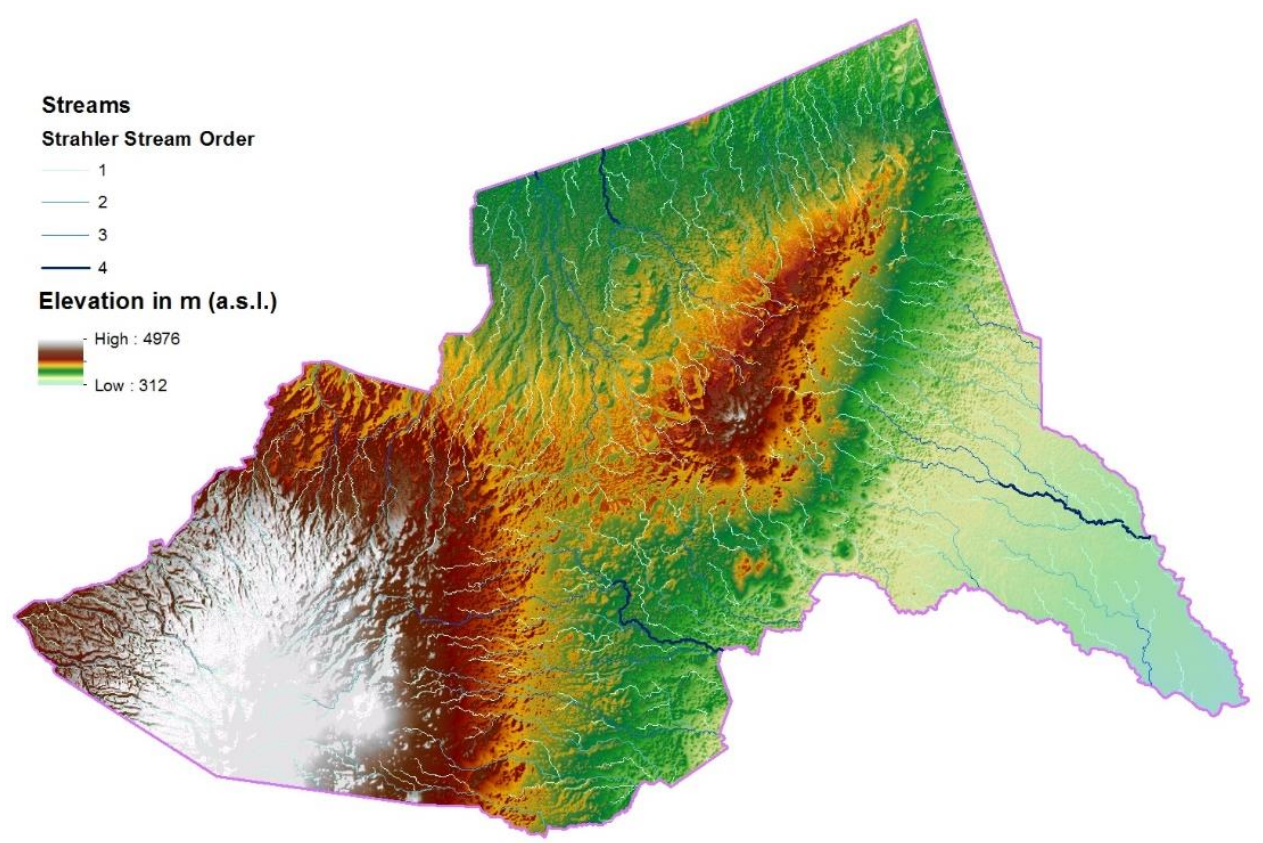

Figure. 1: DEM showing elevation and generated stream network for the study area

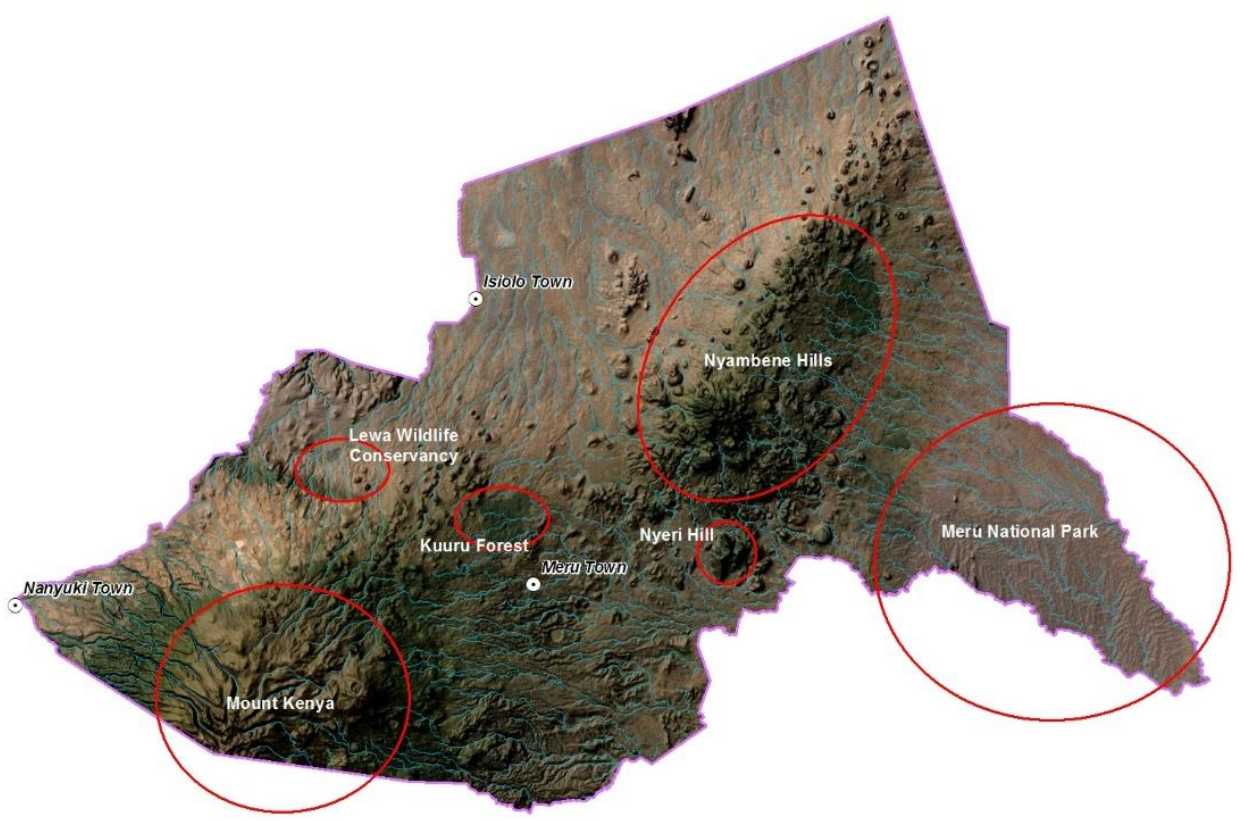

Figure. 2: Hillshade showing major relief features, generated stream/lineament and location of major towns within the study area

The numerical ranking system, another DRASTIC component was used to assess the groundwater potential for each hydrogeological variable. The system contains two parts, weights and ranges. Each modified DRASTIC parameter has been assigned a relative weight in percentage (heuristically arrived at based on the interpretation of the relative significance of the factor), with the most significant factor having higher percentage and vice versa in regards to their influence to existence of groundwater as presented in Table 2. In turn, each of the variables is "sub-divided" into either numerical ranges (e.g. elevation in meters above sea level.) or media types (e.g. soil texture) hereby called ranges, signifying how a factor impacts on groundwater existence. Table 2 illustrates the weights and ranges of the variables employed in the model. 
Table 2: Variable, weight and ranges employed in modeling

\begin{tabular}{|c|c|c|c|}
\hline Variable/Factor & Weight \% & Classification & Ranging \\
\hline Lithology & 10 & Rock type classes & $\begin{array}{l}\text { Igneous, Metamorphic, Sedimentary and } \\
\text { unconsolidated rocks (4 classes) }\end{array}$ \\
\hline $\begin{array}{l}\text { Surface drainage } \\
\text { and lineament }\end{array}$ & 22 & $\begin{array}{l}\text { Drainage/lineament } \\
\text { density }\end{array}$ & High to low density (4 classes) \\
\hline Soil & 8 & Soil texture & $\begin{array}{l}\text { Very clayey, Clayey, Loamy and Sandy (4 } \\
\text { classes) }\end{array}$ \\
\hline Slope & 20 & Slope & 4 classes of degree of terrain sloppiness \\
\hline $\begin{array}{l}\text { Rainfall } \\
\text { distribution }\end{array}$ & 8 & Annual rainfall & 4 classes of annual rainfall in $\mathrm{mm}$ \\
\hline Land cover & 12 & $\begin{array}{l}\text { Major land cover } \\
\text { classes }\end{array}$ & $\begin{array}{l}\text { Forest, } \\
\text { Agriculture/plantation, built-up and Barren (5 } \\
\text { classes) }\end{array}$ \\
\hline Topography & 20 & Elevation & $\begin{array}{l}4 \text { classes of low to high altitude in meters above } \\
\text { sea level. }\end{array}$ \\
\hline Total & 100 & & \\
\hline
\end{tabular}

\section{MODIFIED DRASTIC INDEX}

Mathematically, the final result for each hydrogeologic setting (i.e. geographic area) is a numerical value obtained using the equation below

Ground water Potential $=[($ Drainage $) r *($ Drainage $) w]+$ $[($ Lithology $) r *($ Lithology $) w]+[($ Soil $) r *($ Soil $) w]+[($ Slope $) r *$ $($ Slope $) w]+[($ Rainfall $) r *($ Rainfall $) w]+[($ Land cover $) r *($ Land Cover $) w]+[($ Topography $) r *$ (Topography $) w]$

$$
\text { Groundwater Potential }=\sum_{i=1}^{7} R_{i} \sum_{j=1}^{c_{i}} W_{j}
$$

Where: $\quad R=$ ranging and $W=$ weight of parameter
A high numerical index resulting from Equation is assumed to be indicative of a geographic area having more potential to groundwater.

Placed within a spatial context, the methodology was based upon a series of seven maps, one for each hydrogeological parameter as presented in Figure. 3. The modified DRASTIC methodology was implemented by means of visual map comparison, resampling, reclassification and overlay within GIS/RS softwares. 

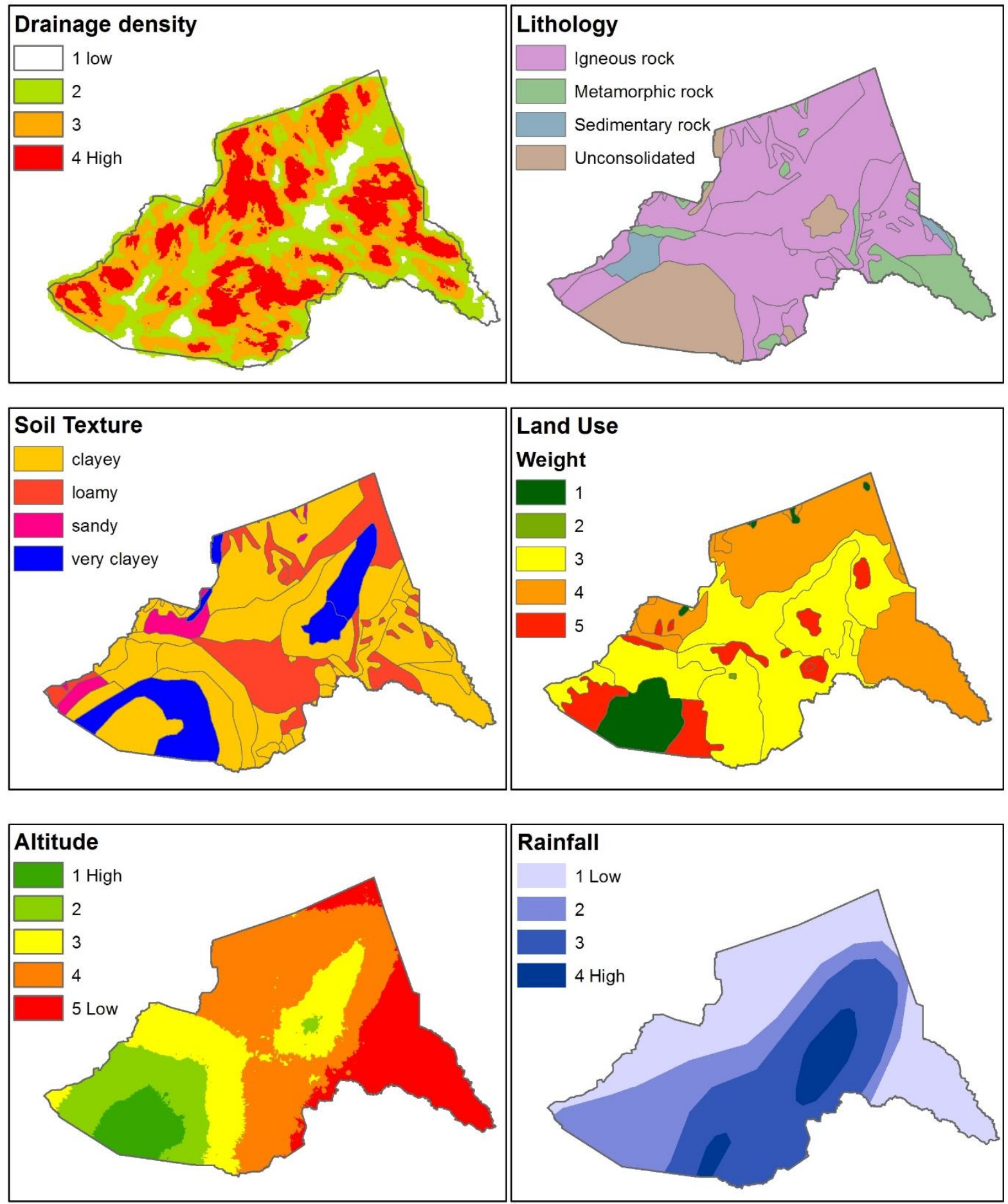

Fig. 3: Processing results: Drainage and lineament density; Lithology; Soil texture; weighted Land use factors; Altitude; and Annual Rainfall.

\section{RESULTS AND DISCUSSION}

Figure 4 illustrates the result of the modified DRASTIC based map overlay. From this map, it can be seen that the central and eastern parts of the county are suitable for groundwater exploration. South western parts of the county, closest to Mount Kenya have lowest suitability mainly due to altitude, rock type and slope factors. 


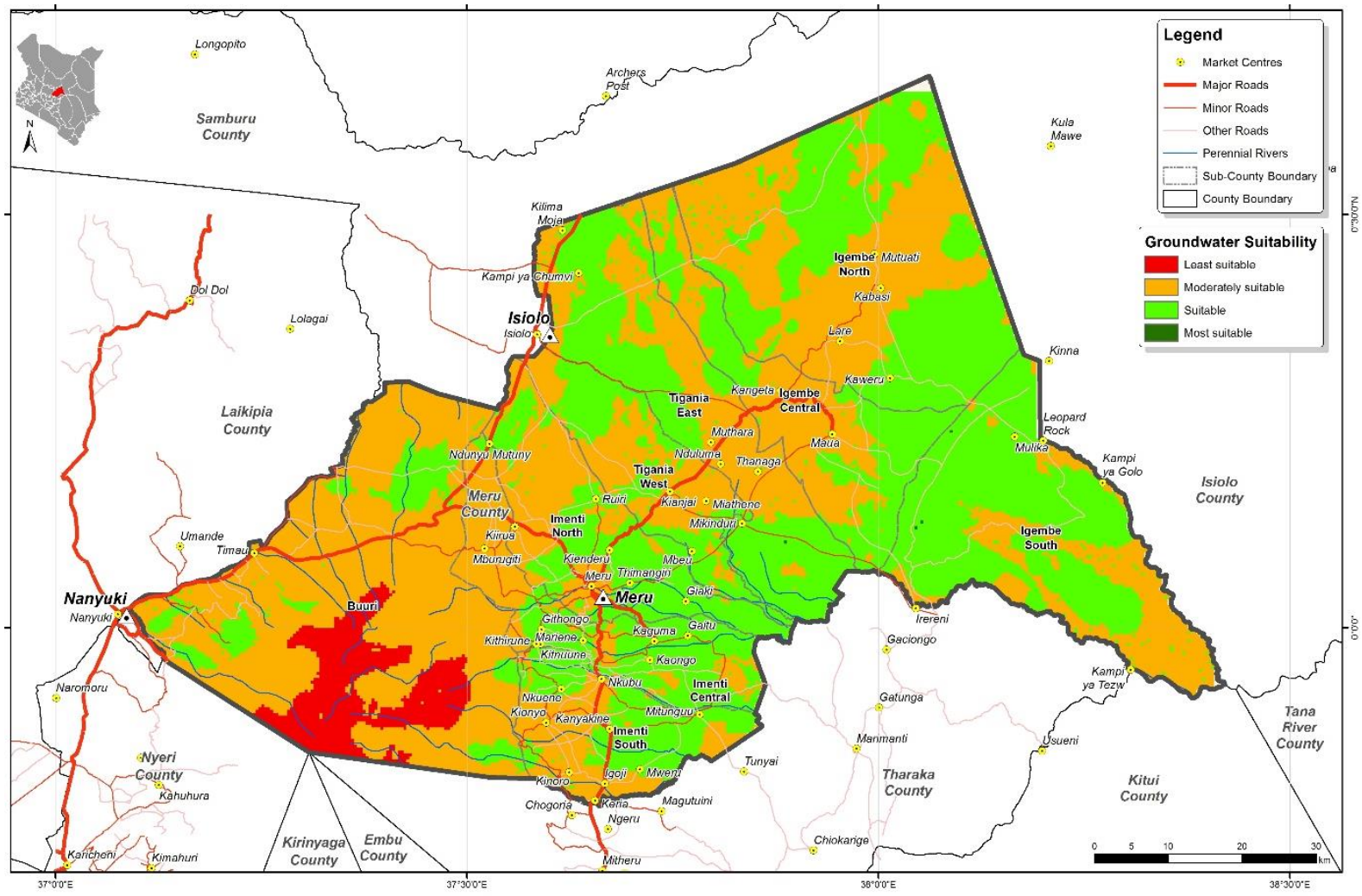

Figure. 4: Groundwater suitability map of Meru County

\section{CONCLUSION}

The use of geospatial technologies in estimating the groundwater potential of Meru County was achieved through preparation of both raster (satellite images) and vector datasets and modeling within GIS/RS software. Modified DRASTIC approach in delineation of groundwater potential zones was applied. The study revealed most suitable areas for groundwater prospecting were shown to be those in the central, northern and eastern areas of the county. Existing water points are available in those regions, thus validating the study.

\section{REFERENCES}

[1] Aller L, Lehr JH, Petty R, Benett T (1987). DRASTIC: a standardized system to evaluate groundwater pollution potential using hydrogeological setting. Journal for Geological Society, India.

[2] Crawford TJ, Brackett DA (1995). Ground water in Igneous and Metamorphic Rocks; Low-angle lithologic contacts related to site-specific control of ground water occurrence. Proceedings of the 1995 Georgia Water Resources Conference, held April 11 and 12, 1995, at The University of Georgia

[3] Ganapuram S, Kumar G, Krishna I, Ercan K, Demirel M (2009). Mapping of groundwater potential zones in the Musi basin using remote sensing data and GIS. Advances in Engineering Software.

[4] Kamaraju M, Bhattacharya A, Reddy G, Rao G, Murthy G, Rao T (1996). Ground-water potential evaluation of West Godavari District, Andhra Pradesh State, India A GIS approach. Ground Water.

[5] Kumar B (2010). Integrated approach using RS and GIS techniques for mapping of ground water prospects in Lower Sanjai watershed, Jharkhand, International Journal of Geomatics and Geosciences, Vol. 1, No 3.
[6] Kuria DN, Gachari MK, Macharia MW and Mungai E (2012). Mapping groundwater potential in Kitui District, Kenya using geospatial technologies, International journal of water Resources and Environmental Engineering, Vol. 4 No 1

[7] Mati BM, Muchiri JM, Njenga K, Penning de Vries F, Merrey DJ (2005) Assessing water availability under pastoral livestock systems in droughtprone Isiolo District, Kenya. Working Paper 106. Colombo, Sri Lanka: International Water Management Institute.

[8] Murphy KSR (2000). Groundwater potential in a semi-arid region of Andhra Pradesh - a geographical information system approach. International Journal. Remote Sensing.

[9] Pandiyani PS, Annadurai R (2013) Groundwater potential Zoning at Kancheepuram using GIS Techniques. RACST - Engineering Science and Technology: An International Journal (ESTIJ), ISSN: 2250-3498, Vol.3, No.1, February 2013

[10] Rahman A (2008). A GIS based DRASTIC model for assessing groundwater vulnerability in shallow aquifer in Aligarh, India Department of Geography, Faculty of Natural Sciences, Jamia Millia Islamia University, Jamia Nagar, New Delhi, India

[11] Rao PJ, Harikrishna P, Srivastav SK, Satyanarayana PV, Rao BD (2009) Selection of groundwater potential zones in and around Madhurwada Dome, Visakhapatnam District - A GIS approach.

[12] Sankar K (2002). Evaluation of groundwater potential zones using Remote Sensing data in upper Vaigai river basin, Tamil Nadu, India. J. Indian Society Remote Sensing.

[13] Sener E, Davraz A, Ozcelik M (2005). An integration of GIS and remote sensing in groundwater investigations.

\section{AUTHORS}

First Author - Gitonga, D

Second Author - Eshton, B. 
